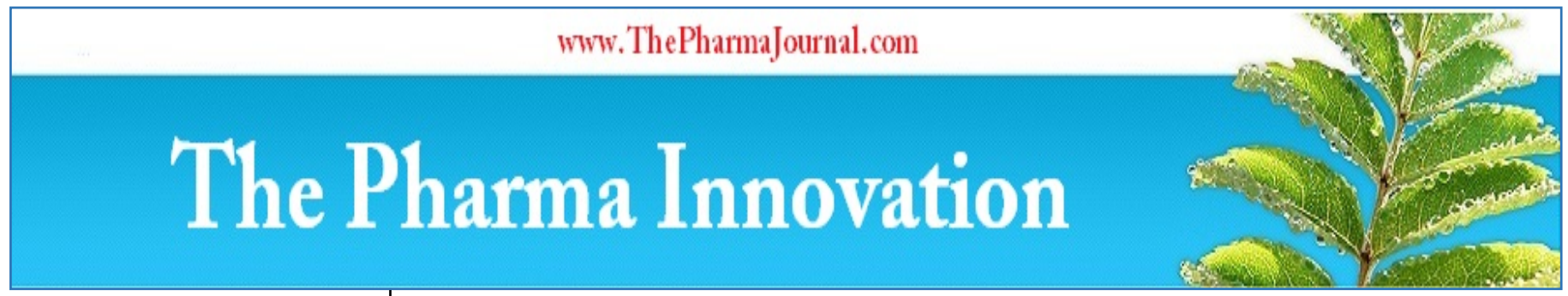

ISSN (E): 2277 - 7695

ISSN (P): 2349-8242

NAAS Rating: $\mathbf{5 . 0 3}$

TPI 2020; 9(11): 362-365

(C) 2020 TPI

www.thepharmajournal.com

Received: 06-09-2020

Accepted: 18-10-2020

Geetashree Bori

Department of Family Resource

Management and Consumer

Science, College of Community

Science, Assam Agricultural

University, Jorhat, Assam, India

Nandita Bhattacharyya

Department of Family Resource

Management and Consumer

Science, College of Community

Science, Assam Agricultural

University, Jorhat, Assam, India

Corresponding Author:

Geetashree Bori

Department of Family Resource

Management and Consumer

Science, College of Community

Science, Assam Agricultural

University, Jorhat, Assam, India

\title{
Muscle fatigue and grip strength among commercial handloom weavers
}

\section{Geetashree Bori and Nandita Bhattacharyya}

DOI: https://doi.org/10.22271/tpi.2020.v9.i11f.5381

\begin{abstract}
Muscle fatigue has been a major concern associated with occupational injury. The repetitive task with the hand gripping and motion of wrist for long hours in a static posture develop fatigue and decrease in productivity arising health related issues. The present study aimed to assess the muscle fatigue of handgrip strength among commercial handloom weavers and find the correlation between body pain and fatigue. The study included 180 women weavers from commercial handloom units in three different types of handloom weaving, namely, throw shuttle loom, fly shuttle loom, and frame loom using jacquard. The mean and SD of the percentage decrease in grip strength was found highest in frame-loom using jacquard with a percentage of $12.29 \pm 5.78$ in the right hand. The correlation between body pain and decrease in grip strength was found to be highly significant with the shoulder pain and hand pain in the right hand of frame-loom using jacquard.
\end{abstract}

Keywords: Body pain, grip strength, handloom, muscle fatigue, women weavers

\section{Introduction}

Handloom weaving plays a significant role in the upliftment of socio-economic status and economic necessity of the women weavers of Assam. According to all India fourth handloom census report, 2019-20 more than 10 lakhs of women handloom weavers of Assam are involved in weaving and allied activities ${ }^{[1]}$. Weaving is a dependable source of income for the women weavers. Handloom weaving requires repetitive hand motions of the weavers with high activity levels of the flexor muscle of the forearm and hands. These hand motions are adopted while drawing the string to and fro, putting designs in between the weft yarns, while beating the reed, yarn breaking and mending, rolling the cloth beam etc. It is noticed that due to the increasing demand for hand-woven products the women weavers are compelled to invest more time in weaving activity for increasing production and supplying the market demands. This process, on the other hand, reduces the resting period of weavers and involves overusing muscles which may further lead to fatigue. An approach to design development strategies would build a user-friendly relationship to improve the occupational health and work performance ${ }^{[2]}$.

Muscle fatigue reduces the muscle's activity to generate force due to exhaustion and strenuous activity. Prolong and strong contraction of the muscles leads to the development of fatigue due to an inadequate blood supply to the muscles that inhibits oxygen supply resulting in increased production of lactic acid in the blood and further affecting the work performance with a reduction in work capacity and productivity ${ }^{[3]}$. Additionally, muscle fatigue is a complex concept that involves both physiological and psychological aspects of the industrial workers, and to evaluate muscle fatigue in the hand, the performance of the worker's grip strength is considered ${ }^{[4]}$.

The commercial handloom weavers perform the manual task for more than 6 hours in a day. Prolong exposure to repetitive tasks reduces the efficiency of the worker's muscular effort and further reduces work performance. It is noticed that when the task is carried out with inappropriate posture, work method, work tools and accessories, work-related musculoskeletal disorders occur. Significantly, measures should be taken to eliminate the cause of fatigue and occupational stress rather than inculcate treatment ${ }^{[5]}$. Several studies have shown that musculoskeletal disorders are one of the major problems among the handloom weavers ${ }^{[6-8]}$. Likewise, they are therefore prone to suffer occupational injuries and work-related diseases which may indirectly affect health, performance and comfort ${ }^{[9]}$. This condition may occur due to the incompatibility of the worker with the workstation, tools and equipment, anthropometric measurements, poor working posture, exertion, environmental factors and work method. 
Ergonomics is concerned with safety, comfort and ease of use of the tools and accessories to fit between the worker and the work. Application of ergonomics in the existing working environment of the handloom weavers would help reduce muscular fatigue in the muscles with increase productivity, performance and better health and safety. Thus, the present study was carried out:-

(i) to assess the muscle fatigue in handgrip strength of the handloom women weavers in three types of looms and

(ii) to evaluate the correlation between the body pain and grip strength of the women weavers for the development of tools and accessories.

\section{Materials and Methods}

\subsection{Selection of women weavers}

A total of 180 women weavers actively involved in commercial weaving were selected from the Lakhimpur district of Assam, purposively for the study. The weavers were selected based on the weaving done in three types of handlooms i.e., Frame-loom using jacquard, frame-loom using dobby, throw-shuttle loom using dobby. In each category of looms sixty weavers were selected purposively. Each participant in the study was interviewed and observed while using the loom. Various parameters used for the present study were weight, height and time, recorded by weighting balance, anthropometric rods and stopwatch. Grip strength was taken with the help of a handheld grip dynamometer to measure the decrease in grip strength of the women weavers. The body pain and muscle fatigue were observed with the help of a Borg scale CR-10 rating from 0 to 10 for the feeling of exertion in the body parts.

Based on the observations and different task performance of the weavers, few problems were identified. Among the problems identified are muscle fatigue in the hand and forearm in the current working condition in three different types of looms. Data were collected using a questionnaire based on the following (a) physical characteristics of the weavers; (b) Decrease in grip strength of both right and left hand in three different types of handloom weaving. (c) Evaluation of the correlation between the body pain and grip strength of the women weavers in three different types of weaving

\subsection{Grip fatigue}

Grip strength of the handloom weavers was measured by using a grip dynamometer, before the performance of the activity and after the activity. The grip-fatigue was calculated by using the formula:

$\%$ Decrease in grip strength $=\frac{\mathrm{Sr}-\mathrm{Sw}}{\mathrm{Sr}} \times 100$

Where, $\mathrm{Sr}$ is the strength of the muscle at rest and $\mathrm{Sw}$ is the strength of the muscle at work. A decrease in grip strength indicates a reduced muscular activity, is an indicator of muscle stress.

\subsection{Statistical analysis}

Frequency, percentage, mean, standard deviation, paired-t test, Correlation coefficient were worked out for different parameters and data were interpreted by using SPSS version 20.0 Statistical package program.

\section{Result and Discussion}

Handloom sectors are the main contributors for women weavers in livelihood generation. Demographically, the handloom weavers of Assam comprises of total 10.9 lakhs of weavers and a single state which accounts for $77.4 \%$ with the highest production of shawls, mekhela-chaddar, stole, scarf etc. ${ }^{[1]}$. Data provides information on the involvement of a large workforce next to agriculture. The finding of the study shows the age and BMI of the weavers, decrease in grip strength of both the hands and the correlation between the decrease in grip strength and the body pain of the weavers.

\subsection{Age and BMI of the weavers}

Table 1 shows that the participation of the weavers in the present study was found highest in the age group of 31-40 years with $56.6 \%$ and lowest in the age group of 51-60 years with $6 \%$.The highest mean height was found to be $155.5 \mathrm{~cm}$ in the age group of 21-30 years and the lowest mean height in $31-40$ years with $153.3 \mathrm{~cm}$. The highest mean weight was found $55 \mathrm{~kg}$ in the age group of 41-50 years and the lowest mean weight of $49 \mathrm{~kg}$ in the age group of $41-50$ years. The mean value of Body Mass Index was found normal in all the age groups.

Table 1: BMI of the respondents according to age group

\begin{tabular}{|c|c|c|c|c|c|}
\hline Age & Frequency & Height (cm) & Weight (Kg) & BMI & Remarks \\
\hline $21-30$ & $41(22.7)$ & 155.5 & 51.5 & 21.4 & Normal \\
\hline $31-40$ & $102(56.6)$ & 153.8 & 50.26 & 21.47 & Normal \\
\hline $41-50$ & $25(13.8)$ & 154 & 55 & 23.19 & Normal \\
\hline $51-60$ & $12(6)$ & 153.2 & 49.08 & 20.96 & Normal \\
\hline
\end{tabular}

\subsection{Decrease in grip strength of the women weavers in} three types of handloom weaving

Grip strength is a measure of muscular strength. The decrease in handgrip strength indicates exertion and muscle fatigue due to the long duration of work and repetitive movement of the hand. From the result given in Table 2 it is observed that the mean and SD of the percentage decrease in grip strength is found highest with $12.29 \pm 5.78$ in the right hand of frameloom using jacquard followed by the left hand with 11.75 \pm 3.67 . The decrease in grip strength in both the right hand and left hand of throw-shuttle loom using dobby was found lowest when compared between three types of looms. A paired t-test was done to observe the difference between the left hand and right hand of the weavers in three types of looms. But no significant difference was observed between both the hands, due to the performance of a similar type of activity in both the hands.

Table 2: Decrease in Grip strength of the respondents in three different types of looms $n=180$

\begin{tabular}{|c|c|c|c|}
\hline Looms & Right hand (Mean \pm SD) & Left hand (Mean \pm SD) & P-value \\
\hline Throw shuttle loom using dobby $(\mathrm{n}=60)$ & $10.09 \pm 4.45$ & $10.03 \pm 3.78$ & $0.913 \mathrm{NS}$ \\
\hline Fly shuttle loom using Dobby $(\mathrm{n}=60)$ & $10.34 \pm 4.39$ & $10.47 \pm 5.22$ & $0.813 \mathrm{NS}$ \\
\hline Frame-loom using jacquard $(\mathrm{n}=60)$ & $12.29 \pm 5.78$ & $11.75 \pm 3.67$ & $0.250 \mathrm{NS}$ \\
\hline
\end{tabular}

Significant at 0.05 level 


\subsection{Correlation between the decrease in grip strength and body pain of the women weavers}

Table 3 reveals and Figure 1 the correlation between the decrease in grip strength of the women weavers in three different types of looms and pain in different parts of the body. The correlation between body pain and both the right/ left hand was also observed. The correlation table shows that a decrease in grip strength in the right hand of frame-loom using jacquard shows high significant values with the back pain, shoulder pain, elbow pain and hand pain compared to the other two looms. The shoulder pain and hand pain in the right hand of frame-loom using jacquard was found highly significant (at $0.05 \%$ level and $0.01 \%$ level of significance) with the decrease in grip strength of the respondents. The data presented shows a few values that are not significant with each other and few values with low correlation.

\section{Discussion}

The present study reveals that the maximum participation of the women weavers was in the age group 31-40 years with $56.6 \%$ having normal BMI. As the study was based on commercial handloom weaving, therefore only those weavers were included who performed the weaving activity for more than 5-6 hours a day excluding the pregnant, lactating women and persons with a severe ailment. Based on the present study, the decrease in handgrip strength of frame loom using jacquard was more compared to frame loom using dobby and throw shuttle loom using dobby. Besides, the other highly involved activities like drawing the harness, reaching for the dobby/jacquard, throwing the shuttle, putting designs in the fabric the decrease in grip strength was found more in frameloom using jacquard than frame-loom using dobby. It may be due to maximum exertion of the worker while performing the activity in frame-loom using jacquard. Figure 1 shows the simple scatter plot correlation between a decrease in grip strength of right hand and hand pain in throw shuttle loom using dobby, fly-shuttle loom using dobby, and frame -loom using Jacquard. The figure shows that the increase in hand pain was more in the jacquard loom. It is also evident from the figure that an increase in hand pain increases the percentage decrease in grip strength. Similar studies were conducted to assess the muscle fatigue in the hand among different industrial workers - Cotelez et al., 2016 in footwear industry workers, Bhattacharyya and Chakrabarti, 2012 on Cumulative trauma disorder in tea leaf pluckers and musculoskeletal pain among female weavers by Dewangan and Sora, 2015 [4, 5, 8]. These conditions of muscle fatigue were found among weavers when they assume different posture at work while performing various activities ${ }^{[10-13]}$ and do not take adequate rest in between the work hours, at the same time stress of completing their task in the required time. The high significant value was observed in the hand pain, shoulder pain, back pain and elbow pain of the weavers. Thus, there exists a high relationship between the pain and decrease in grip strength of the weavers. Jacquard looms are mostly used for commercial weaving purposes. Due to long hours of weaving activities done in static and awkward postures the worker's discomfort level increases with exertion in the muscles and gradually they experience fatigue. Thus, muscle fatigue reduces the worker's capability and production which indirectly hampers the productivity ${ }^{[5]}$ and income earning of the weavers. It was found that most of the weaver's wage is dependent on the number of items produced, the quality and design of the product and the time taken for completing each product item. Therefore, an application of ergonomics and anthropometric measurements ${ }^{[15]}$ with proper posture and seat height with better features of handheld gripping tools and equipment would help reduce muscle fatigue with improvement in productivity, health and safety.

\section{Conclusion}

Women weavers involve a large workforce in handloom weaving activity. The weavers use old and traditional gripping tools and accessories which may not be compatible with the worker's requirements, leading to experience fatigue among weavers. Further, the increasing muscle fatigue would hamper the health and income of the weaver with reduced productivity. A short break between the work hours would help in getting the relief of physiological stress and fatigue. Therefore, an ergonomically equipped workplace would help in building a sound working environment among the commercial women handloom weavers.

Table 3: Correlation between body pain and grip strength of the women weavers in three types of looms

\begin{tabular}{|c|c|c|c|c|c|c|}
\hline \multirow{2}{*}{$\begin{array}{c}\text { Pain in } \\
\text { body parts }\end{array}$} & \multicolumn{2}{|c|}{$\begin{array}{c}\text { Throw shuttle } \\
\text { loom using dobby }\end{array}$} & \multicolumn{2}{c|}{$\begin{array}{c}\text { Fly-shuttle loom } \\
\text { using Dobby }\end{array}$} & \multicolumn{2}{c|}{$\begin{array}{c}\text { Frame-loom } \\
\text { using jacquard }\end{array}$} \\
\cline { 2 - 7 } & RH & LH & RH & LH & RH & LH \\
\hline Back & $.358^{* *}$ & $.223^{* *}$ & $.597^{* *}$ & $.176^{*}$ & $.786^{* *}$ & $.228^{* *}$ \\
\hline Shoulder & $.437^{* *}$ & $.438^{* *}$ & $.545^{* *}$ & $.117 \mathrm{NS}$ & $.891^{* *}$ & $.416^{* *}$ \\
\hline Neck & $.036 \mathrm{NS}$ & $.093 \mathrm{NS}$ & $.403^{* *}$ & $.040 \mathrm{NS}$ & $.345^{* *}$ & $.360^{* *}$ \\
\hline Elbow & $.670^{* *}$ & $.255^{* *}$ & $.737^{* *}$ & $.349^{* *}$ & $.747^{* *}$ & $.432^{* *}$ \\
\hline Hand & $.593^{* *}$ & $.360^{* *}$ & $.733^{* *}$ & $.416^{* *}$ & $.818^{* *}$ & $.545^{* *}$ \\
\hline Finger & $.091 \mathrm{NS}$ & $.105 \mathrm{NS}$ & $.069 \mathrm{NS}$ & $.049 \mathrm{NS}$ & $.143 \mathrm{NS}$ & $.125 \mathrm{NS}$ \\
\hline
\end{tabular}

RH - Right Hand, LH - Left Hand, NS - Not Significant,*Significant at 0.05 level, $* *$ Significant at 0.01 level

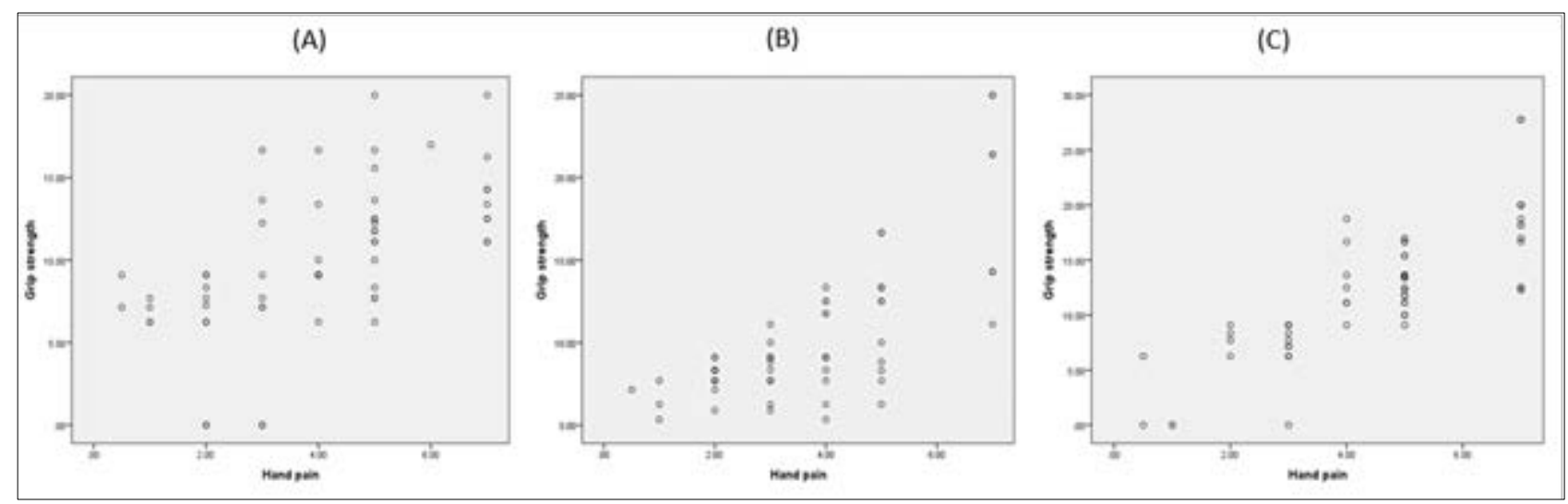

Fig 1: Simple scatterplot correlation between decrease in grip strength of right hand and hand pain in (A) throw shuttle loom using dobby, (B) fly-shuttle loom using dobby, (c) Frame-loom using Jacquard 


\section{References}

1. Fourth all India handloom census, Office of The Development Commissioner for Handlooms, Ministry of Textiles Government of India, 2019-20.

2. Bhattacharyya N, Chakrabarti D. Ergonomics- A way to occupational wellness of workers engaged in Industrial activities: Special reference to Assam. Journal of Ergonomics 2016;6(3):1-5.

3. Kiser DM, Rodgers SH. Ergonomic design for people at work. John and Wiley \& Sons, Inc 1986;2:17-46.

4. Cotelez LA, Serra MVGB, Ramos E, Zaia JE, Tolido FO, Quemelo PRV. Handgrip strength and muscle fatigue among Footwear industry workers, Fisioter Mov 2016;29(2):317-324.

5. Bhattacharyya N, Chakrabarti D. Ergonomic basket design to reduce cumulative trauma disorders in the leaf plucking operations, Work 2012;41:1234-1238.

6. Choobineh A, Hosseini M, Lahmi M, Jazani RK, Shahnavaz H. Musculoskeletal problems in Iranian handwoven carpet industry: Guidelines for workstation design. Applied Ergonomics 2007;38:617-624.

7. Nag A, Vyas H, Nag P. Gender differences, work stressors and musculoskeletal disorders in weaving industries, Industrial Health 2010;48:339-348.

8. Dewangan KN, Sora K. Job demand and human-machine characteristics on musculoskeletal pain among female weavers in India. Proceedings $19^{\text {th }}$ Triennial Congress of the IEA, Melbourne, 2015.

9. Pandit S, Kumar P, Chakrabarti D. Ergonomic problem prevalent in handloom units of north east India. International Journal of Scientific and Research Publications 2013;3:1.

10. Bori G, Bhattacharyya N. Postural Assessment of women workers involved in various handloom activities. International Journal of Current Microbiology and Applied Sciences 2020;9(10):414-420.

11. Banerjee P, Gangopandyay S. A Study on the Prevalence of Upper Extremity Repetitive Strain Injuries among the Handloom Weavers of West Bengal. Journal of Human Ergology 2003;32:17-22.

12. Bori G. Hand Anthropometry and grip strength of women weavers in handloom Industry of Lakhimpur District, Assam. International journal of research in applied, natural and Social Sciences 2017;5(7):91-96.

13. Chantaramanee N, Taptagaporn S, Piriyaprasarth P. The assessment of occupational ergonomic risks of handloom weaving in Northern Thailand. Thammasat International Journal of Science and Technology 2015;20(4):29-37.

14. Nag A, Nag PK, Desai H. Hand anthropometry of Indian women. Indian Journal of Medical Research 2003;117:260-269.

15. Borg G. Borg's perceived exertion and pain scales. Champaign, IL: Human Kinetics, 1998, 104. 